\title{
Facebook, Social Networking, And Business Education
}

\author{
Steven A. Taylor, Ph.D., Illinois State University, USA
}

Jamie R. Mulligan, Ph.D., Illinois State University, USA

Chiharu Ishida, Ph.D., Illinois State University, USA

\begin{abstract}
Brown (2012) asserts that faculty perceptions of Web 2.0 for teaching will influence its adoption. For example, social media's influence on educational delivery is growing (Hrastinski and Dennon 2012). Zulu et al. (2011) note that business educators are only beginning to understand social networking related to education. We report an exploratory inquiry that confirms the growing evidence that many undergraduate business students do not support the use of Facebook as part of their formal academic relationships. However, an argument is presented that while existing tools for social networking such as Facebook may offer limited pedagogical utility, social networking as a concept none-the-less offers significant potential.
\end{abstract}

Keywords: Social Networking; Facebook; Business Education; Learning Theory; Constructivist; Web 2.0

\section{INTRODUCTION}

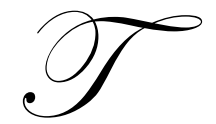

he emergence of Web 2.0 has led to the rapid growth of social media and mobile internet use among US teens and young adults over the course of last several years (Lenhart et al., 2010). Hrastinski and Dennen (2012) review a special issue on social media use in higher education and identify a number of ways in which social media can support the social, networking, and informational dissemination missions of universities, as well as a number of challenges. Of particular importance for the current research is Brown's (2012) assertion that faculty perceptions of the potential efficacy and appropriateness of Web 2.0 tools will be critical to adoption of Web 2.0 tools in pedagogical practices. The current research generalizes this proposition to include student perceptions of Facebook use in pedagogy as one of the most popular of Web 2.0 social networking tools available to faculty at this point in time.

The popular teaching literature is filled with exhortations to use Facebook to enhance faculty-student relationships. Peluchette and Karl (2010) point out that Facebook is the leading site for college students. It is therefore not surprising that academicians have considered the potential of Web 2.0 tools such as social networking media (e.g., Facebook, MySpace, Twitter) for enhancing education (Blankenship 2011, Galagan 2009, Granitz and Koernig 2011, Greenhow et al. 2009, Wankel 2009), as well as post-graduation employment (Zulu et al. 2011). However, Karl and Peluchette (2011) report evidence that a large number of students remain suspicious and uneasy about friend requests from faculty members. The study reported herein first demonstrates similar results in an independent university setting. None-the-less, we construct an argument for not abandoning social networking concepts in pedagogy in spite of the apparent limits in the use of Facebook. Impediments to better use of social networking in pedagogy include poor definition of key theoretical concepts, meager linkages between social networking practices and learning theories, and a need to consider emerging theories of knowledge (e.g., constructivism) in business pedagogy. 
Table 1

Goal Related Concepts (Adapted from Taylor et al. 2006)

\begin{tabular}{llll}
\hline \multicolumn{1}{c}{ Goal Type } & \multicolumn{1}{c}{ Purpose } & \multicolumn{1}{c}{ Explanation } & \multicolumn{1}{c}{ Findings (Males and Females) } \\
\hline $\begin{array}{l}\text { Superordinate } \\
\text { Goal }\end{array}$ & $\begin{array}{l}\text { Why do I want to } \\
\text { achieve that for } \\
\text { which I strive? }\end{array}$ & $\begin{array}{l}\text { Constitute the reasons or motives for } \\
\text { goal striving, thus justifying or } \\
\text { rationalizing one's chosen focal goal. } \\
\text { Similar in function to beliefs and } \\
\text { evaluations in attitude theory. }\end{array}$ & $\begin{array}{l}\text { Social and professional/academic lives } \\
\text { should be separate; Many potential } \\
\text { negative consequences; No need for } \\
\text { such tools }\end{array}$ \\
Focal Goal & $\begin{array}{l}\text { What is it that I strive } \\
\text { for? }\end{array}$ & $\begin{array}{l}\text { Corresponds to a respondent's goal } \\
\text { intention. }\end{array}$ & $\begin{array}{l}\text { To NOT use online social networking } \\
\text { social media tools as part of their } \\
\text { academic relationships. }\end{array}$ \\
$\begin{array}{l}\text { Subordinate } \\
\text { Goal }\end{array}$ & $\begin{array}{l}\text { How can I achieve } \\
\text { that for which I } \\
\text { strive? }\end{array}$ & $\begin{array}{l}\text { These represent the means to goal } \\
\text { achievement, thus corresponding to } \\
\text { instrumental behaviors. }\end{array}$ & $\begin{array}{l}\text { A variety of reasons and justifications } \\
\text { (see Figures 1 and 2). }\end{array}$ \\
\hline
\end{tabular}

\section{THE STUDY}

We undertook an exploratory qualitative study to investigate student impressions and use of online social networking tools such as Facebook and Twitter in their academic relationships, particularly with faculty. First, we generated (visual) goal maps using the method advocated by Taylor et al. (2006), which can help clarify underlying goals related to the use of popular social networking tools as part of pedagogical practices. The identified goal patterns can help explain behavioral motivations (see Table 1). Second, we then conducted exploratory focus groups. Respondents participated in a professional quality on-campus focus group facility, and represented a convenience sample of undergraduate students taking Introduction to Marketing courses. This course is required of all business majors and is populated by students across academic disciplines. Respondents were awarded extra credit for study participation. A total of four focus groups were conducted, divided by gender (Focus group $1=14$ females; Focus group $2=11$ females; Focus group $3=18$ males; and Focus group $4=14$ males). Literature generally recommends against mixing genders in focus groups (Churchill and Brown, 2004; Fern, 2001; Krueger, 1988). The focus group data and goal-mapping information was interpreted by three independent PhD-trained academicians, with differences arbitrated by discussion and unanimous agreement.

\section{Results}

Figure 1 presents the results (by gender) of the goal mapping exercises. The circles indicate the concepts representing the superordinate goals of the students in using social networking for academic purposes. The subordinate goals are indicated by the arrows extending down from the circles. There was surprising consistency in respondents' superordinate goals associated with not using popular social networking software as part of their academic pursuits, both within and between genders. The first reason involves the consistently voiced perspective that social and professional lives should be separate, i.e., compartmentalized. These results are consistent with those reported by Lenhart (2009), and suggest the importance of boundaries for this cohort (Czerniewicz and Brown, 2010). The second reason involves concerns that future employers and/or faculty/staff of universities might actively respond negatively to information they see on social networking sites (both text and pictures). Finally, there was a consistent perspective identified that there is no perceived need to use tools such as Facebook and Twitter to meet course expectations and/or to enhance faculty/student relationships in academic settings.

The dialogue portion of the focus groups further reinforced that respondents do not appear to view these popular online social networking tools as generally valuable for education (see Table 2). The "Key Take-Away" column in Table 2 suggests that respondents view online social networking tools to largely relate to their personal, non-professional relationships in terms of their perceptions of perceived value. In terms of what contributes to the denominator of value perceptions, privacy concerns appeared prevalent, consistent with Houghton and Johnson (2010) and the 2010 American Customer Satisfaction Index (ACSI) E-Business Report (http://www.theacsi.org/index.php). 

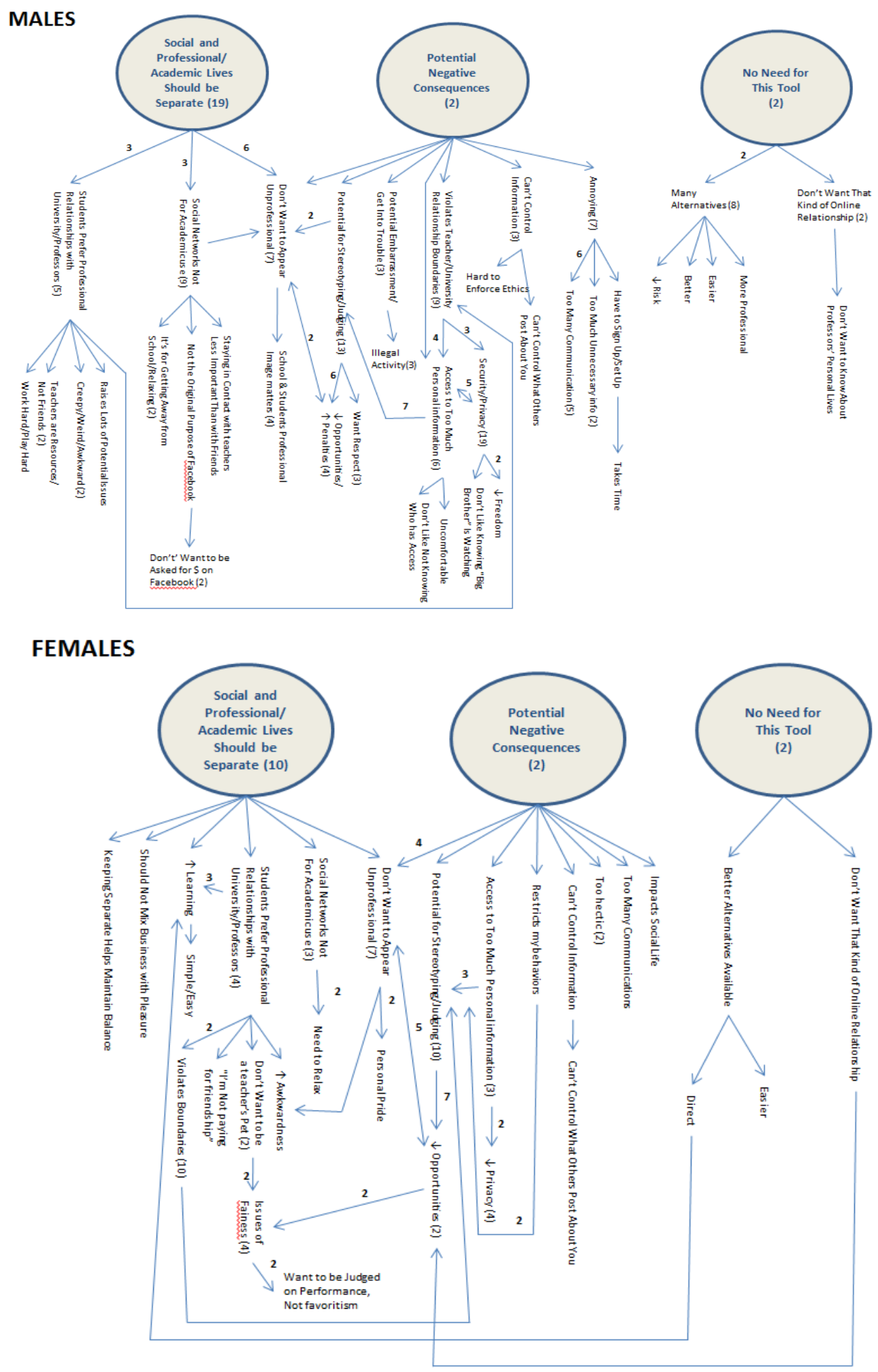

Figure 1

Goal Maps by Gender 
Table 3 presents a summary of the focus group dialogue specifically related to the use of online social networking tools for academic use. The comments reinforce the superordinate goals identified in Figure 1. In particular, the boundary issues appear to predominate. In short, the risks appear to significantly outweigh the (apparent lack of) possible value-enhancing attributes for academic relationships. Thus, the results suggest potential difficulty for business educators trying to employ online social networking tools as they currently exist as part of the academic learning experience for some students. The results of the exploratory study also highlight the need to clarify the theoretical foundations of social networking as a concept, as opposed to merely equating popular online social networking tools such as Facebook with the more general concept of "social networking" itself.

\section{DEFINING SOCIAL NETWORKING CONCEPTS}

Boyd and Ellison (2008) define social networks as web-based services that allow individuals to construct a public or semi-public profile within a bounded system, articulate a list of users with who they share a connection, and view and traverse the list of connections and those made by others in the system (Zula et al. 2011). However, our study suggests that simply adopting emerging online social networking tools in pedagogical practices may not ensure bridging the intellectual and educational divide for all students. This conclusion appears consistent with other emerging evidence (Johnson, 2009; Facer and Selwyn, 2010; Haferkamp et al., 2011; Henderson et al., 2011; McHaney, 2011; Sharpe et al., 2010). Thus, it remains unclear specifically how educational scholarship might be transformed within Web 2.0, particularly vis-à-vis online social networking tools, and whether or not all the effects will be positive (Greenhow et al. 2009, Granitz and Koernig 2011).

\section{Distinguishing "Social Networks" as a Concept from "Online Social Network Tools"}

We assert that one issue attenuating the use of social networking in the management of pedagogy involves the ambiguity associated with "social networks" as a theoretical concept versus as a set of online tools. They are not the same thing. We first consider the definition of a "network" since "social networking" would appear to involve some form of a "network." Unfortunately, even a cursory review of the literature identifies a plethora of different conceptualizations and emphasis concerning the concept of "networks." For example, Iacobucci (1996) demonstrates that the term "network" can refer to a verb describing the initiation and sustenance of interpersonal connections for some purpose, or as a noun describing a collection of actors and their structural connections. Wachhaus (2009) asserts that appropriately conceptualizing a "network" can also be problematic due to disagreements as to whether networks are "real" or metaphors and/or whether networks should be viewed as structures or processes. Araujo and Easton (1996) present a classification of 10 different network approaches in socioeconomic systems. Muijs et al. (2010) specifically state that there remains no clear understanding and definition of what is meant by "networking" in education.

None-the-less, we argue that the emerging literature can help inform the development of a potentially commensurable theoretical definition of "social networks" as a concept for use by business educators by framing the discussion around the Web. 2.0 and theories of knowledge. Granitz and Koernig (2011) argue that the Web 2.0 represents a philosophy that can advance experiential learning through increased student construction of educational materials, by bringing more of the outside world into business "classrooms," and modifying the role of the professor. Greenhow et al. (2009) assert that it is both a platform for innovative technologies as well as a space wherein users are as important as the content they upload and share with others. These authors further assert that Web 2.0 conceptually embodies "knowledge" as collective agreement, and present evidence that Web 2.0 has the potential to enhance educational value. 
Table 2

Focus Group Results (Concepts of Value by Gender)

\begin{tabular}{|c|c|c|c|c|}
\hline \\
\hline \multirow{2}{*}{ Question } & \multicolumn{2}{|l|}{ Female } & \multicolumn{2}{|l|}{ Male } \\
\hline & Key Take-Away & Summary Quotes & Key Take-Away & Summary Quotes \\
\hline $\begin{array}{l}\text { Concept of } \\
\text { Value: } \\
\text { Benefits/ } \\
\text { What you get }\end{array}$ & 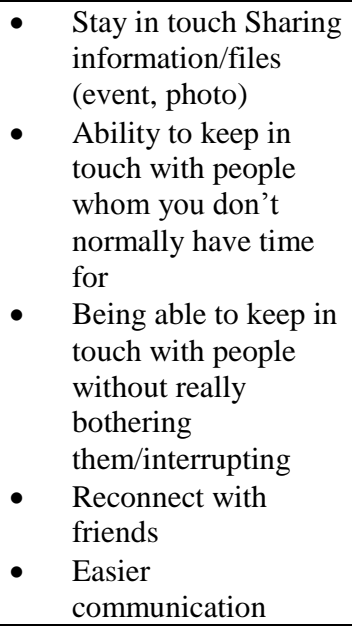 & $\begin{array}{l}\text { - } \quad \text { "Keep up with people you know" } \\
\text { - } \quad \text { Don’t have to interrupt them or } \\
\text { - } \quad \text { keep calling each other back." } \\
\text { relations me to maintain that you would have } \\
\text { otherwise not been able to keep." } \\
\text { - "It's a convenience." } \\
\text { - "It's more efficient." }\end{array}$ & $\begin{array}{ll}\text { - } & \text { Stay in touch } \\
\text { - } & \text { Get updates about } \\
\text { friends/family } \\
\text { - } & \text { Networking } \\
\text { (connect and } \\
\text { reconnect) } \\
\text { - Develop } \\
\text { relationships } \\
\text { - Share music/files } \\
\text { with friends } \\
\text { Convenient } \\
\text { communi-cation } \\
\text { - Plan events } \\
\text { Entertainment/pass } \\
\text { time }\end{array}$ & $\begin{array}{l}\text { - "Share music, promote shows/band/club events" } \\
\text { - "More convenient way to contact people at odd hours" } \\
\text { - "Easy to keep up with everyday life" } \\
\text { - "Easy to keep up with people who live far away" } \\
\text { - "Get a sense of what my friends and family are doing } \\
\text { "Quick interaction because people check it more often } \\
\text { than email." } \\
\text { "I think what you get out of it is a lot of convenience, } \\
\text { you don't have to remember phone numbers or } \\
\text { anything." } \\
\text { "Convenience - You aren't going to call up someone } \\
\text { late at night. It's easy to see what everyone is doing; } \\
\text { you don't have to call everyone individually." }\end{array}$ \\
\hline $\begin{array}{l}\text { Concept of } \\
\text { Value: } \\
\text { Costs/What } \\
\text { you give up }\end{array}$ & $\begin{array}{ll}\text { - } & \text { Privacy } \\
\text { - } & \text { Time } \\
\text { - } & \text { Meaningful } \\
& \text { relationships } \\
\text { - } & \begin{array}{l}\text { Potentially a source } \\
\text { of trouble }\end{array} \\
\text { - } & \text { Lingo - ability to } \\
& \text { type correctly }\end{array}$ & $\begin{array}{l}\text { - } \quad \text { "Everyone sees what you write" } \\
\text { - } \quad \text { infompanies may use your } \\
\text { - } \quad \text { "I have privacy concerns of job } \\
\text { - } \quad \text { searches in the future." } \\
\text { - Once you get on sometimes you } \\
\text { look up and it's like an hour later." } \\
\text { your wall, then everyone knows." }\end{array}$ & $\begin{array}{ll} & \text { Giving away } \\
& \text { personal } \\
\text { information } \\
\text { - } & \text { Time } \\
\text { - } & \text { Privacy } \\
\text { - } & \text { Potential negative } \\
& \text { posts } \\
\text { - } & \text { Security } \\
\text { - } & \text { Personal } \\
& \text { interaction }\end{array}$ & $\begin{array}{l}\text { - Other people posting what you don't want } \\
\text { - Bigger issue the closer you get to graduation } \\
\text { - "I give up a lot of time that cuts into my school." } \\
\text { - "Mom is on Facebook - can see what I'm up to." } \\
\text { "Isn't that the whole point of Twitter - you get people } \\
\text { to follow you so that they always know what you are } \\
\text { doing?" } \\
\text { - } \quad \text { It macebook is really really creepy." }\end{array}$ \\
\hline
\end{tabular}


Table 3

Focus Group Results (Relationships with Professors/Staff by Gender)

\begin{tabular}{|c|c|c|c|c|}
\hline \\
\hline \multirow{2}{*}{ Question } & \multicolumn{2}{|l|}{ Female } & \multicolumn{2}{|l|}{ Male } \\
\hline & Key Take-Away & Summary Quotes & Key Take-Away & Summary Quotes \\
\hline $\begin{array}{l}\text { What do you } \\
\text { think of using } \\
\text { social } \\
\text { networking for } \\
\text { relationships } \\
\text { with } \\
\text { professors? } \\
\text { Would you } \\
\text { "Friend" your } \\
\text { professor? }\end{array}$ & 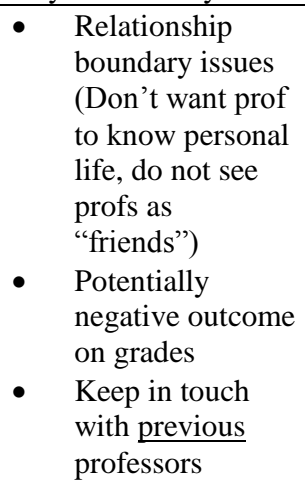 & $\begin{array}{l}\text { - "I think it's a little weird, it's kind of } \\
\text { awkward." } \\
\text { "It might affect how they act towards me in } \\
\text { class." } \\
\text { "It's a privacy issue, if you don't want to be } \\
\text { on a social network, then they shouldn't } \\
\text { make you." } \\
\text { - "I would be uncomfortable with it." } \\
\text { - "It depends on the professor." } \\
\text { - "I think boundaries are good." Your school } \\
\text { and your personal life should be separate." }\end{array}$ & 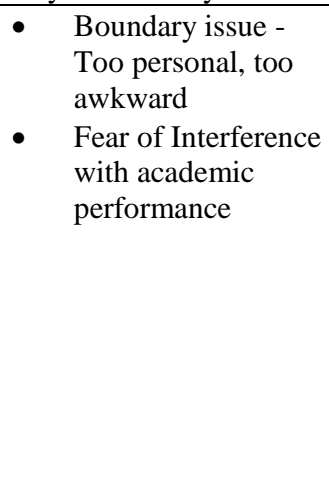 & $\begin{array}{l}\text { - "I felt like it would put my academic career in } \\
\text { jeopardy" } \\
\text { "Teacher-student relations should be a separate } \\
\text { thing." } \\
\text { "The biggest thing would be that teachers may } \\
\text { judge you." } \\
\text { - "It's a boundary thing." } \\
\text { "I think it's a good way to stay in contact, so that } \\
\text { you can get information immediately." } \\
\text { "I don't want to share information with you. It's a } \\
\text { boundary thing." } \\
\text { "It's not the right tool. That's what office hours } \\
\text { are for." }\end{array}$ \\
\hline $\begin{array}{l}\text { What do you } \\
\text { think of using } \\
\text { social } \\
\text { networking for } \\
\text { academic use? }\end{array}$ & $\begin{array}{ll}- & \text { Boundary issues } \\
- & \text { Lack of } \\
& \text { Convenience/ } \\
& \text { Efficiency } \\
\text { - } & \text { Would like a } \\
\text { different tool } \\
\text { [other than } \\
\text { Facebook] for } \\
\text { academic use }\end{array}$ & $\begin{array}{l}\text { - } \quad \text { "I like to keep classes and social life } \\
\text { separate. There should be some } \\
\text { boundaries." } \\
\text { - "I think they should be separate." } \\
\text { - "LinkedIn is more appropriate for } \\
\text { academic/professional use." } \\
\text { - "I would like something like blackboard, } \\
\text { but that is easier to use." } \\
\text { - "Education majors can't have pictures of } \\
\text { alcohol on their Facebook or they can get } \\
\text { thrown out of the program" } \\
\text { - "You can form 'groups' for class use." } \\
\text { "Facebook isn't for school" }\end{array}$ & $\begin{array}{l}\text { - Risk with } \\
\text { boundaries } \\
\text { - } \quad \text { Privacy issue } \\
\text { "Unprofessional } \\
\text { impression" } \\
\text { Difference between } \\
\text { 'friends' and } \\
\text { forming a 'group' } \\
\text { for academic use } \\
\text { Some see benefits } \\
\text { of SN, but want } \\
\text { another tool for } \\
\text { academic use. }\end{array}$ & $\begin{array}{l}\text { - "Unprofessional" } \\
\text { - "They are not my friends" } \\
\text { - LinkedIn is different } \\
\text { - Want to keep "personal" communication } \\
\text { - "personal" } \\
\text { - "They can look at your Facebook page" } \\
\text { - If it was a tool separate from your personal } \\
\text { "I wouldn't add you on Facebook, but I would } \\
\text { on Twitter." } \\
\text { "It's good for sharing information, even for } \\
\text { school, but needs to be separate from your } \\
\text { personal information." }\end{array}$ \\
\hline
\end{tabular}




\section{Web 2.0 and the Emergence of Constructivist Theories of Knowledge}

These evolving views of knowledge have significant learning implications. Han (2010) summarizes the influence of Web 2.0 on theories of knowledge and argues that knowledge as traditionally conceived (as reasoned, stable, and linear) must be rethought in the information age. Han asserts that traditional theories of knowledge fail to provide the proper critical social analytics for theorizing new media because they do not recognize emerging conceptualizations of the circulation, production, and functionality of knowledge. Thus, consistent with emerging thought about learning in a digital age (Baker 2010; Sharpe et al. 2010), evidence is growing for greater consideration of emerging socio-cultural (e.g., constructivist) perspectives (McKenna and Conradi 2010).

An example of a constructivist perspective is Jerome Bruner's meaning-centered psychology (e.g., Bruner 2008). Mattingly et al. (2008) provide a very brief overview of this perspective, which argues that meaning must be at the heart of investigations of activity and the mind. Meaning is not determined by innate biological drives nor created in the individual mind. Rather, to speak of "meaning" requires starting with culture instead of biology (i.e., sociology enhancing psychological explanations). The reason concerns the centrality of narrative to an understanding of human cognition because any mental science needs to investigate the concept of meaning and processes within culture. Culture provides the possibility of reading the minds of others because meanings are public and communal rather than individualistic and private in a cultural world. Thus, culture (1) delimits and routinizes the ordinary, (2) limits and defines the possible, and (3) offers a way to make sense of violations to culturally-based expectations. Narratives mediate transactions between the ordinary, the unexpected, and possible. Bruner's influence on education is especially well known.

\section{Learning Theory Implications of Considering a Constructivist Perspective}

There are a number of theoretical implications associated with the emergence of Web 2.0 and a constructivist perspective. First, how literacy generally emerges may be changing. Baker et al. (2010) argue that new literacies are being called for (e.g., information literacy, media literacy, and digital literacy per Beetham and Oliver 2011). Baker et al. (2010) further identify the need to view the concept of literacy from a variety of perspectives. Greenhow et al. (2009) also assert arguments for transforming scholarship with Web 2.0. The manner in which such transformations can occur appear heavily reliant on social media (Blankenship 2011, Minocha 2009, Wankel 2009, Wymbs 2011).

Second, where learning occurs may be evolving. Sharpe et al. (2010) argue that the evidence supports the conclusion that the digital age is changing learners into more active participants in their learning experience. Thus, learners are creating their own mixes of physical and virtual environments, some formal and traditional while others are not. Greenhow et al. (2009) similarly argue that Web 2.0 technologies enable hybrid learning spaces that travel across physical and cyber spaces according to the principles of collaboration and participation. Based on this argument, Greenhow et al. (2009) call for a learning ecology perspective that broadens the conceptualization of "classrooms" beyond time and place limits.

This broadened conceptualization of "classrooms" appears consonant with Leander et al.'s (2010) arguments related to the changing social spaces of learning. Consistent with a constructivist perspective, Leander et al. (2010) advocate a socio-cultural perspective that considers processes of thinking and learning beyond the constraints of individual minds to distributions across persons, tools, and learning environments. The socio-cultural perspective further suggests that questions concerning evidence and equity in education are in principle questions about systems and distributions rather than about individuals alone. Specifically, Leander et al. (2010) call for moving from the extant paradigm of seeing education through the lens of the "classroom-as-container" with foundations in psychology to seeing the classroom at a higher level of abstraction vis-à-vis perspectives more closely related to anthropology and sociology. Such a perspective emphasizes new conceptualizations of place, trajectory, and networks. "Place" moves from being a particular locale (e.g., a classroom) to a nexus of relations independent of physical location. This perspective also envisions a different trajectory in that classrooms or other sites of learning become seen less as parking lots and more as intersections. Finally, the perspective moves from activity situated in a particular space and time to actively networking learning resources across space and time. 
Third, the areas of pedagogical emphasis may have to evolve as well. De Freitas and Conole (2010) assert that learning interventions in the future should consist of four inter-related facets: (1) thinking and reflection, (2) conversation and interaction, (3) experience and activity, and (4) evidence and demonstration. Greenhow et al. (2009) call on considering new ways of thinking about how interconnections, content creation and remixing, and interactivity can positively contribute to learners' creative practices, participation and production. The current exploratory research provides a foundation to begin answering this call.

\section{DISCUSSION \& RECOMMENDATIONS FOR BUSINESS EDUCATORS}

The discussion above articulates how the emergence of Web 2.0 has had profound and exciting implications on learning theory. However, the focus of the ABJE is to assist teachers of business related topics in teaching their courses. Therefore, this concluding section presents some practical guidance for business educators interested in embracing social networks and their associated theoretical learning implications in their own pedagogical practices.

First, the results reported herein suggest reluctance among undergraduate students in using currently available online social media tools such as Facebook and Twitter to support their academic pursuits, due primarily to issues of boundaries and privacy. However, and importantly, we do not interpret these results as reason to diminish our enthusiasm for increased use of Web 2.0 tools or social networking concepts by business educators. Rather, for those faculty interested in utilizing general online social networking tools such as Facebook and Twitter, we suggest faculty be sensitive to the results reported herein by having a candid discussion with students as to the advantages and disadvantages to such practices from both student and faculty perspectives. If students "opt in," then the likelihood of success in terms of faculty-student relationship quality will be enhanced. In addition, faculty should be sensitive to the privacy and boundary concerns identified herein, and make an obvious, concerted, and communicable effort to address these issues in discussions with students. The measure of success for such efforts will be achieved trust between students and the faculty member (a measureable concern). It is worth noting that academic institutions might differentiate themselves by developing their own internal social networking tool as part of their intranet to help alleviate some student concerns.

Second, we encourage business educators to develop a definition of "social networks" as a concept and not a set of online tools. In particular, we encourage business educators to be aware of how social networks are impacting learning theories (as previously discussed herein). For example, if how literacy emerges is changing (now as a social versus an individualistic phenomenon), then there is an apparent duty to consider learning through the lens of social learning theory. A great deal of insight can be derived from bodies of knowledge from sociology and anthropology. We have previously identified constructivism as one such perspective. A related perspective worth considering is the actor-network (ANT) theory as applied to education (see Fenwick and Edwards 2010).

Finally, these alternative theoretical perspectives have methodological implications. Traditional surveybased measures of student satisfaction may ultimately prove to align poorly with emerging social networking practices in education. Proponents of alternative social networking perspectives have consistently bemoaned the limitations of the popular positivistic (methods driven) approaches. We recognize that such methods have traditionally appealed to business (Tadajewski 2008) and information technology (MacKenzie et al. 2011) scholars, but social networking as a domain of inquiry may significantly benefit from consideration of alternative methodological approaches. For example, the very concept of a "network" may work against growth in our understanding of social influences on business pedagogy (Fenwick 2010, Joseph 2010). Butts (2008) presents a methodological introduction to social network analysis (SNA), characterized as a large and growing body of research on the measurement and analysis of relational structures, that business educators might consider. Clearly, greater study is required to better understand the nature of such fundamental concepts as "networks" in social networks associated with business education. Specifically, we encourage greater integration of theory and techniques from sociology and anthropology to help better understand social business phenomenon in business education. If it is true that theory often follows methods, then such an approach might be insightful. 


\section{AUTHOR INFORMATION}

Steve Taylor, (Ph.D., Florida State University) is a Professor of Marketing and the Hinderliter Chair of Business at Illinois State University. His research interests include consumer quality, satisfaction, loyalty, and judgment and decision making. He can be reached at staylor@ilstu.edu. Corresponding author.

Jamie R. Mulligan, (Ph.D., Purdue University) is an Assistant Professor of Technology Management, Illinois State University. Her research interests include simulations and applied statistics, as well as issues related to sustainability. She can be reached at jwiela2@ilstu.edu.

Chiharu Ishida (Ph.D., Virginia Tech) is Associate Professor of Marketing in at the College of Business, Illinois State University. Her research interest includes the area of Business-to-Business (B-to-B) relationship management, as well as interdisciplinary research, such as applying the B-to-B literature to B-to-C (e.g., consumer-brand relationships), and vice versa. She can be reached at cishida@ilstu.edu.

\section{REFERENCES}

1. Araujo, L. \& Easton, G. (1996). Networks in socioeconomic systems: A critical review," in Networks in Marketing. Iacobucci, D. (Ed.), Thousand Oaks: Sage Publications, 63-107.

2. $\quad$ Baker, E. A. (2010). The New literacies: Multiple Perspectives on Research and Practice. New York: Guilford Press.

3. Baker, E. A., Pearson, P. D., \& Rozendal, M. S. (2010). Theoretical perspectives and literacy studies: An exploration of roles and insights," in The New Literacies: Multiple Perspectives on Research and Practice. Baker, E. A. (Ed.). New York: The Guilford Press, 1-22.

4. Beetham, H. \& Oliver, M. (2010). The changing practices of knowledge and learning," in Rethinking Learning for a Digital Age, Sharpe, R., Beetham, H. \& De Freitas, S. (Eds.). New York: Routledge, 155169.

5. Blankenship, M. (2011). How social media can and should impact higher education," The Education Digest, March 2011, 39-42.

6. Brown, S. A. (2012). Seeing Web 2.0 in context: A study of academic perceptions. Internet and Higher Education, 15 (2012), 50-57.

7. Bruner, J. (2008). Culture and mind: Their fruitful incommensurability. Ethos, 36 (1), 29-45.

8. Butts, C. T. (2008). Social network analysis: A methodological introduction. Asian Journal of Social Psychology, 11, 13-41.

9. Churchill, G. A. and Brown, T. J. (2004). Basic Marketing Research. Mason, OH: South-Western.

10. Czerniewicz, L. \& Brown, C. (2010). Strengthening and weakening boundaries: Students negotiating technology mediated learning," in Rethinking Learning for a Digital Age. Sharpe, R., Beetham, H. \& De Freitas, S. (Eds.). New York: Routledge, 142-152.

11. De Freitas, S. \& Conole, G. (2010). The influence of pervasive and integrative tools on learners' experiences and expectations of study," in Rethinking Learning for a Digital Age. Sharpe, R., Beetham, H. \& De Freitas, S. (Eds.). New York: Routledge, 15-30.

12. Facer, K. \& Selwyn, N. (2010). Social networking: Key messages from the research," in Rethinking Learning for a Digital Age. Sharpe, R., Beetham, H. \& De Freitas, S. (Eds.). New York: Routledge, 31-42.

13. Fenwick, T. (2010). (un)Doing standards in education with actor-network theory. Journal of Education Policy, 25 (2), 117-133.

14. Fenwick, T. \& Edwards, R. (2010). Actor-Network Theory in Education. London: Routledge, Taylor \& Francis Group.

15. Fern, E. F. (2001). Advanced Focus Group Research. Thousand Oaks, CA: Sage Publications.

16. Galagan, P. (2009). Twitter as a learning tool. Really. $T+D$, March 2009, 28-31.

17. Granitz, N. \& Koenig, S. K. (2011). Web 2.0 and marketing education: Explanations and experiential applications. Journal of Marketing Education, 33, 57-72.

18. Greenhow, C., Robelia, B. \& Hughes, J. E. (2009). Learning, teaching, and scholarship in a digital age. Educational Researcher, 38 94), 246-259. 
19. Haferkamp, N. \& Kramer, N. C. (2011). Social comparison 2.0: Examining the effects of online profiles on social-networking sites. Cyberpsychology, Behavior, and Social Networking, 14 (5), 309-314.

20. Han, S.(2010). Theorizing new media: Reflectivity, knowledge, and the Web 2.0. Sociological Inquiry, 80 (2), 200-213.

21. Henderson, M., de Zwart, M., Lindsay, D., \& Phillips, M. (2011). Will u friend me? Legal risks and social networking sites, Monash University, http://newmediaresearch.educ.monash.edu.au/moodle/pluginfile.php/2119/mod_label/intro/SNSandRisks_ EducationResource.pdf, Accessed April 14, 2011 [online].

22. Houghton, D. J. \& Johnson, A. N. (2010). Privacy, social network sites, and social relations. Journal of Technology in Human Services, 28, 74-94.

23. Hrastinski, S. and Dennen, V. (2012). Social media in higher education: Introduction to the special issue. Internet and Higher Education, 15 (2012), 1-2.

24. Iacobucci, D. (1996). Introduction, in Networks in Marketing, Iacobucci, D. (Ed.), Thousand Oaks: Sage Publications, xiii-xx.

25. Johnson, D. (2009). Don’t confuse social networking with educational networking. The Blue Skunk Blog, http://doug-johnson.squarespace.com/blue-skunk-blog/2009/3/12/dont-confuse-social-networking-witheducational-networking.html, Accessed April 12, 2011, [online].

26. Joseph, J. (2010). The problem with network theory. Labor History, 51 (1), 127-144.

27. Karl, K. A., \& Peluchette, J. V. 2011. "Friending" professors, parents, and bosses: A Facebook conundrum. Journal of Education for Business, 86, 214-222.

28. Krueger, R. A. (1988). Focus groups: A practical guide for applied research. Thousand Oaks, CA: Sage Publications.

29. Leander, K. M., Phillips, N. C., \& Taylor, K. H. (2010). The changing social spaces of learning: Mapping new mobilities. Review of Research in Education, 34, 329-394.

30. Lenhart, A. (2009). Adult and social network websites. Pew Internet \& American Life Project, Pew Research Center, Washington, D.C., http://www.pewinternet.org/Reports/2009/Adults-and-SocialNetwork-Websites.aspx, Accessed April 13, 2001, [online].

31. Lenhart, A., Purcell, K., Smith, A., \& Zickuhr, K. (2010). Social media \& mobile internet use among teens and young adults. Pew Internet \& American Life Project, Pew Research Center, Washington, D.C. http://www.pewinternet.org/Reports/2010/Social-Media-and-Young-Adults.aspx. Accessed April 13, 2001, [online].

32. MacKenzie, S. B., Podsakoff, P. M., \&Podsakoff, N. P. (2011). Construct measurement and validation procedures in MIS and behavioral research: Integrating new and existing techniques. MIS Quarterly, 35 (2), 293-334.

33. Mattingly, C., Lutkehaus, N. C., \& Throop, C. J. (2008). Bruner's search for meaning: A conversation between psychology and anthropology. Ethos, 36 (1), 1-28.

34. McHaney, R. (2011). The New Digital Shoreline: How Web 2.0 and Millennials are Revolutionizing Higher Education. Herndon, VA: Stylus Publishing, LLC.

35. McKenna, M. C. \& Conradi, K. (2010). Can behaviorist and constructivist applications coexist in the new literacies?, in The New Literacies: Multiple Perspectives on Research and Practice, Elizabeth A. Baker (Ed.). New York: The Guilford Press, 41-60.

36. Minocha, S. (2009). Role of social software tools in education: A literature review. Education + Training, $51(5 / 6), 353-369$.

37. Muijs, D., West, M., \& Ainscow, M. (2010). Why network? Theoretical perspectives on networking. School Effectiveness and School Improvement, 21 (1), 5-26.

38. Peluchette, J., \& K. Karl. 2010. Examining students' intended image on Facebook: "What were they thinking?! Journal of Education for Business. 85, 30-37.

39. Pew (2010), "Millennials: A portrait of Generation Next," Pew Research Center, http://pewsocialtrends.org/files/2010/10/millennials-confident-connected-open-to-change.pdf, [online].

40. $\quad$ Sharpe, R., Beetham, H. \& De Freitas, S. (2010). Rethinking Learning for a Digital Age. New York: Routledge.

41. Sharpe, R., Beetham, H., De Freitas, S. \& Conole, G. (2010). An introduction to rethinking learning for a digital age, in Rethinking Learning for a Digital Age, Sharpe, R., Beetham, H., \& De Freitas, S. (Eds.). New York: Routledge, 1-12. 
42. Tadajewski, M. (2008). Incommensurable paradigms, cognitive bias and the politics of marketing theory. Marketing Theory, 8 (3), 273.

43. Taylor, S. D., Bagozzi, R. P., Gaither, C. A., and Jamerson, K. A. (2006). The bases of goal setting in the self-regluation of hyptertension. Journal of Health Psychology, 11, 141-161.

44. Wachhaus, A. (2009). Networks in contemporary public administration: A discourse analysis. Administrative Theory \& Praxis, 31 (1), 59-77.

45. Wankel, C. (2009). Management education using social media. Organization Management Journal, 6, 251262.

46. Wymbs, C. (2011). Digital marketing: The time for a new academic major has arrived. Journal of Marketing Education, 33 (1), 93-106.

47. Zulu, K., K. K. Yarrish, \& W. Pawelzik. (2011). An analysis of the differences between student age and social networking utilization within a school of business. American Journal of Business Education, 4 (9), $37-42$. 
NOTES 